\title{
Improvisation within management: oxymoron, paradox, or legitimate way of achieving?
}

\section{Stephen A. Leybourne}

Plymouth Business School

Drake Circus, Plymouth, PL4 8AA, UK

Fax: +44 (0)1752 232247

E-mail: Stephen.Leybourne@plymouth.ac.uk

\begin{abstract}
This paper considers the evolving literature on Organizational Improvisation, considering a number of different perspectives relating to its use and acceptance within a typology of modern management styles. Cunha et al.'s (1999) work is identified as a starting point, and particular attention is given to the gradual integration of improvisational working styles into the lexicon of management theory.

The nature of improvisation, and its contradictory stance when considered against the understood notions of managerial control, is examined. Attention is then directed at the use and acceptance of improvisational working practices in the domain of that contemporary flexible organisation. The evidence presented here supports the oxymoronic and paradoxical nature of organisational improvisation, and offers the view that it is a valid and useful addition to the lexicon of management skills in the turbulent and fast-changing environment that persists in the first decade of the 21 st century.
\end{abstract}

Keywords: improvisation; oxymoron; paradox; flexibility; working styles; control; change; intuition; bricolage.

Reference to this paper should be made as follows: Leybourne, S.A. (2007) 'Improvisation within management: oxymoron, paradox, or legitimate way of achieving?', Int. J. Management Concepts and Philosophy, Vol. 2, No. 3, pp.224-239.

Biographical notes: Steve Leybourne is a Senior Lecturer at Plymouth Business School. He has a PhD from Cardiff Business School, has a range of published papers, and has presented at national and international peer-reviewed conferences, including the last four US Academy of Management conferences. His research interests include organisational improvisation, innovation, and the implementation of change using projects. Current funded research is investigating improvisation within high value 'Superyacht' projects. He was also a member of the EPSRC-funded 'Rethinking Project Management' network, and is a member of numerous professional and academic associations. 


\section{Introduction}

There is evidence of a new trend within the management of modern, proactive organisations. This trend, which side-steps traditional models of management that have been accepted for long periods within the management literature, relates to the use of organisational improvisation to explore new ways of achieving the objectives of those organisations within a number of areas. These areas include new product development (Akgün and Lynn, 2002; Moorman and Miner, 1998b; Kamoche and Cunha, 2001), cognition (Augier and Vendolø, 1999; McGinn and Keros, 2002), entrepreneurial activity (Baker et al., 2003; Hmieleski and Corbett, 2003), organisational learning (Akgün et al., 2003; Barrett, 1998; Chelariu et al., 2002; Miner et al., 2001; Moorman and Miner, 1998a), change (Brown and Eisenhardt, 1997; Macredie and Sandom, 1999; Orlikowski, 1996), time (Ciborra, 1999), planning (Crossan et al., 1996; Cunha et al., 2001; Eisenhardt, 1997), team working (Cunha and Cunha, 2001), and organisational structure (Hatch, 1999; Pavlovich, 2003), amongst others.

Although this body of literature has been growing substantially since the mid 1990s, building on early philosophical ideals from Ryle (1979), and more organisationally oriented work within Weick (1979), there is still some doubt as to the benefits of improvisational work practices for organisations. Notwithstanding the extensive use of such practices within the project-managed implementation of strategic change (Leybourne, 2002), a recent study (Leybourne and Sadler-Smith, 2004) indicates a minimal link between improvisation and successful project outcomes, and this lack of empirical evidence of links between improvisation and validated success has endured. A review of the literature (for a comprehensive review of the emerging literature to 1998 see Cunha et al., 1999) offers much material that attempts to define, contextualise, and discuss improvisational practices, but a lesser body of empirically-based and theoretically rigorous work that demonstrates the effectiveness of improvisation.

This situation raises the question of where organisational improvisation sits within the field of business and management. The purpose of this paper is therefore to examine improvisation, using the existing literature, in order to locate it within the broad expanse of other literatures available to the management scholar. In the process, it is intended that various dimensions, opinions, and criticisms of improvisational work be examined, to ascertain the current standing of the proposition that improvisation is a useful addition to the lexicon of working styles.

In order to achieve this, it is proposed that initially, a review of the recent literature is offered. This review will build on the excellent exposition offered in Cunha et al. (1999), and will consider recent output that relates to both the theoretical understanding of improvisation, and its practical application. This section will examine and categorise the emerging literature as a series of papers dealing with discrete areas, both processual and socio-behavioural. Following this review, and in order to address the aspirations of the title of this paper, some time will be spent assessing the oxymoronic and paradoxical nature of organisational improvisation, and its growing influence as a legitimate way of achieving. An assessment can then be made about the ways that improvisational working practices affect the modern organisation. Finally, some conclusions will be drawn. 


\section{A review of the recent literature}

Cunha et al. (1999) have already provided an enlightening and comprehensive review of the emerging 1990s improvisation literature, although over the last five years, this literature has evolved and matured. This paper therefore brings that review up to date, and considers where organisational improvisation sits in today's organisations. Cunha et al. formally define improvisation, together with a review of its antecedents, influencing factors, and outcomes. A literature review is included, dividing existing work on theory development in improvisation into first, second, and third stage articles. First stage articles attempt to transpose the improvisational work carried out in jazz extemporising and theatre to organisational contexts. Second stage articles move improvisation away from the arts and into organisations, developing definitions (usually from a grounded theory approach), and building the foundations to allow research of a more positivist leaning. An emerging third stage is also identified, considering amongst other areas, a temporal perspective of organisational improvisation.

As Cunha et al. deal in an extremely comprehensive manner with the literature up to 1998 , it seems inopportune to revisit the mass of early literature in the way that they have already done. There are however a number of interesting aspects of the literature that are exposed by their analysis. Notably, they identify (Table 9 on page 333) the relative dearth of empirical work in the early literature. This is to some extent being rectified, and it is appropriate to offer an abridged review of the post 1998 literature here.

Firstly, and significantly for the acceptance of improvisation as an influential style of achieving, it has joined the lexicon of planning methods (Cunha et al., 2001; Kanter, 2002). Specifically, Cunha et al. (2001, p.67) suggest that a method they label as improvisational scenario planning: "may create an action infrastructure for allowing organizations to plan in real-time, as events and action unfold". They contend that such an approach is appropriate to deal with turbulent environments, provided that managers can abandon the rational decision-making and planning model that underpins the traditional management model. Kanter takes this idea further, positing that through an approach that she labels 'project-by-project' improvisation:

\footnotetext{
"An organization can constantly reinvent itself. An internal marketplace of ideas in which innovators initiate and sell projects replaces the usual decision-making hierarchy. As results from a portfolio of projects accumulate, the organizations direction changes - slowly at first but significantly over time." (Kanter, 2002, p.81)
}

Such an approach may entail risks for an organisation, and will entail a radical shift from traditional prescriptive planning processes, but may bring real benefits in shortening reaction times for organisations in the turbulent environments already outlined.

Planning and organisational structure are closely linked, and elements of the emerging literature are addressing this some components of this linkage. Hatch (1999, p.86) talks about: "conceptual[izing] ambiguity in relation to the empty spaces left by goal incongruence, disagreement on methods or explanations, and by organizational change". Her view, coherently argued and aligned to the now familiar notion of parallels with the composition of jazz music, is that those empty spaces be filled with improvised actions that influence the future strategic direction of the organisation. Vera and Crossan 
(2004) resonate with this view, aligning the need for an organisation to be responsive to the environment with, in their case, theatrical improvisation. Weick (1998) reinforces this perspective, suggesting that:

"the new found urgency in organizational studies to understand improvisation and learning is symptomatic of growing societal concerns about how to cope with discontinuity, multiple commitments, interruptions, and transient purposes that dissolve without warning." (p.551)

Pavlovich (2003) also applies such principles to the development of inter-organisational networks, suggesting that such networks are organised through a process of improvisation.

Some of the earlier empirical work on improvisation considered its use in the development of new products (Brown and Eisenhardt, 1997; Eisenhardt and Tabrizi, 1995; Moorman and Miner, 1998b). This interest in the linkages between improvisation and New Product Development (NPD) has continued. Akgün and Lynn (2002) used quantitative analysis of data from 354 respondents across a range of industry sectors, and concluded that: "team improvisation has a positive impact on speed-to-market under turbulent markets and technologies" (p.124). Kamoche and Cunha (2001) also consider the effects of improvisational techniques on products, focusing specifically on product innovation. They move from a 'first stage' position of considering improvisational product innovation as it parallels jazz improvisation, to a notion that they describe as 'minimal structures', that in turn merges composition and performance. The paper is fundamentally conceptual, but seeks to, and largely succeeds in, raising the debate about improvisation within NPD to a higher level.

There is also a heightened interest in the complexity and interactions that bind the perceived relationships between improvisation and organisational learning. Augier and Vendelø (1999) consider how tacit knowledge is used by improvisers as a source of data that will assist in the resolution of organisational problems. They further suggest that improvisations will benefit from knowledge networks consisting of strong ties. Miner et al. (2001) moves the debate about learning and improvisation forward significantly, identifying four additional constructs that aid our understanding of this area. Significantly, they posit that adaptation, temporal compression, and innovation should be added to the original triumvirate of intuition, creativity, and bricolage (Moorman and Miner, 1998a; Moorman and Miner, 1998b), and that improvisation be considered a special learning type. Chelariu et al. (2002) expands on certain elements of this work, offering a comprehensive review of the way learning interacts with improvisation, and presenting a typology of improvisation. There are also links with the use of improvisation within projects.

The concepts of improvisation are also being applied to other key management imperatives. Strategic change is seen as a major challenge for organisations, and elements of improvisational working practices are being advanced as a possible panacea, or at least an aid. Macredie and Sandom (1999), building on Orlikowski's (1996) work, and Orlikowski and Hoffman's (1997) model, conclude that: "improvisational changes can occur in hierarchical organisations, and that these changes can be implemented successfully using an improvisational perspective provided that ongoing support is available" (p.258). 
Cunha and Cunha (2003) go further, offering improvisational change processes as a contender to fill one of the four vacant slots in Van de Ven and Poole's (1995) taxonomy of theoretical possible change modes.

Entrepreneurship is another of the areas where improvisation is emerging as a useful adjunct to more established modes (Baker et al., 2003; Hmieleski and Corbett, 2003). Baker et al. contend that improvisational processes and issues permeate entrepreneurial activity, and that the concept of bricolage (Levy-Strauss, 1966) is particularly influential. Hmieleski and Corbett (2003) construct a table of differences between improvisation and its related constructs, although they suggest that:



They do however conclude that entrepreneurs both benefit from and learn from successful improvisational activity.

Finally for the purposes of this review, it is important to highlight two additional emerging areas where traditional work practices are being influenced by the emerging improvisation literature. Cunha and Cunha, who are prolific in their output relating improvisation to aligned concepts, have considered links with team work practices (Cunha and Cunha, 2001) and McGinn and Keros (2002) look at improvisation within negotiation. There is also an increasing amount of philosophical discourse relating to the principles and ideals of improvisational practices (Ciborra, 1999; Montuori, 2003). Surely this is an indication that improvisation as an accepted organisational practice is 'coming of age'.

Returning to the title of this paper implies that there are three ways of considering organisational improvisation as an addition to the extensive library of organisational working practices. Although this is a generalisation, as there are many other frameworks or lenses with which organisational improvisation can be analysed, it is now appropriate to consider the three chosen descriptors as they apply to improvisation, namely oxymoron, paradox, and legitimate way of achieving. These will now be considered in turn.

\section{Organisational improvisation as an oxymoron}

In order to consider whether organisational improvisation falls within such a descriptor, it is important to define the term. Collins Concise Dictionary describes an oxymoron as: "an epigrammatic effect, by which contradictory terms are used in conjunction" (p.809). An oxymoron can be construed as a rhetorical antithesis, or more simply as the juxtaposition of incongruous or contradictory terms. However, this is not the first attempt to attach the label of oxymoron to a management area. Weick and Wesley (1996) apply the term to organisational learning, suggesting that the two terms are "essentially antithetical" (p.440), and there are many other examples that consider elements of organisation and management as oxymoronic. Recent areas of the literature include mass customisation within production management (Selladurai, 2004), globalisation (Hashai and Almor, 2004) and control within global organisations (Bijisma-frankema and Koopman, 2004), software development (Orr, 2004; Yu, 2002), democratic leadership 
(Starrat, 2001) and leadership in teams (Zigurs, 2003), corporate entrepreneurship (Thornberry, 2001), consulting (Ozley, 2000), retailing within the banking sector (Dery, 1998), critical management (Grice and Humphries, 1997), and communication management (Gregory, 2003). There is also a particular, and notably earlier, interest in the oxymoronic nature of business ethics (Collins, 1994; Duska, 2000), including specific work on global ethics (Russ-Eft, 2004), and ethics within advertising (Beltramini, 2003; Kilbourne, 1995; Vega, 1998).

Returning to the subject of this exposition, there is a view that organisation relates to order, routine, and the logical arrangement of processes to achieve a given outcome. Indeed, Weick (1998, p.543) suggests that “"organization' itself denotes orderly arrangements for co-operation". Management denotes the orderly arrangement of processes within such an organisation to provide an element of control. Improvisation is however considered in rather more abstract terms, as: "the degree to which composition and execution converge in time" (Moorman and Miner, 1998a, p.698), or: "the conception of action as it unfolds, by an organisation and/or its members, drawing on available material, cognitive, affective and social resources" (Cunha et al. (1999, p.302). Neither of these definitions recognises an element of orderly arrangement, which infers planning, but instead they focus on temporal aspects of developing a series of actions with a sense of immediacy. Cunha et al. (1999) go further, stressing the fact that there is usually no time to marshall additional resources, and that actions have to be based on the use of resources currently available. This is the essence of bricolage, one of the original correlates of organisational improvisation identified in Moorman and Miner (1998a).

It can be seen from this apparent contradiction between organisation as orderly activity, and improvisation as a set of evolving actions emerging out of necessity, that the basic premise of contradiction is met. However, as grammatically, an oxymoron is considered to be two successive words, it may be that if we consider 'improvisation within management' as an oxymoron, then the 'literal' definition is not met. If however we consider 'organisational improvisation', which is the terminology usually adopted within the emerging literature, then the tensions between organisational control and improvisational unplanned activity indicate that there are oxymoronic undertones.

\section{Organisational improvisation as a paradox}

Again, it is appropriate to start with a definition. Collins Concise Dictionary considers a paradox to be: "a seemingly absurd or self-contradictory statement that is or may be true" (p.818). Academically, both Lewis and Dehler (2000) and Clegg et al. (2002) commence their journeys into the consideration of paradox within management with the use of a previous definition, suggesting it is: "the simultaneous presence of contradictory, even mutually exclusive elements" (Cameron and Quinn, 1988, p.2). Paradox has been recognised as an influence in organisational theory for at least two decades (Poole and Van de Ven, 1989). It could be argued that the areas of business and management are beset by paradoxes, and the wider literature offers recent examples that present paradoxical situations in many areas. These include innovation (Andriopoulos, 2003; Meirowitz, 2004), change (Davis et al., 1997; O'Connor, 1995), resistance to change (Kan and Parry, 2004), leadership (Ma et al., 2004) public sector management (Hood, 2004; Roberts, 2002; van Thiel and Leeuw, 2002), teams (van den Broek et al., 2004), downsizing (Littler and Innes, 2004), organisational control (Sundaramurthy and Lewis, 
2003), customer relationship management (Law et al., 2003), employee flexibility (Kahn, 2002), knowledge management (Mohr and Sengupta, 2002; Snowden, 2002; Yates-Mercer and Bawden, 2002), homeworking (Pearlson and Saunders, 2001), and performance development (Beer, 2001).

The basic premise of a managerial or organisational paradox is therefore that those 'seemingly contradictory' factors that should cause an element of tension actually produce some benefit or increased performance. Hatch and Ehrlich (1993, p.505) suggest that paradox has become one of the: "powerful new themes in the study of organizations", and if we return to Cameron and Quinn (1988), they posit that this arises because: "disconfirmation, contradiction, and nonlinearity are inherent in all organizations" (p.14). It is unquestionably widely recognised that organisations are moving further away from the proccessual, oversimplified progressions offered in early organisational theory, and that management in the modern progressive organisation is far less certain. This raises questions about how to ensure control and flexibility, how to plan and create temporal and organisational space for creative activity, and how to manage team-working and collaboration and the conflict caused by coalitions of political resistance. Employees therefore need to be comfortable with the natural tensions occurring in organisations, and deal with and solve apparent contradictions that are common in the modern progressive organisation.

Improvisation could be seen as a problematic concept when judged against these seemingly contradictory questions. The more recent literature has highlighted many requirements and conditions for organisational improvisation that resonate strongly with these issues. Clegg et al. (2002) suggest that all organisation is based on the fundamental paradox that it is a community of: "free, creative, independent human subjects", but that the organisation aspires to a regime of: "organization, order, and control" (p.483). There is little doubt that this attitude has softened over time, and it is now accepted that the balance is tipping in favour of accessing and exploiting the talents of employees, and that in order to do this, the reins of control are being loosened. Clegg et al. (2002) further progress their argument that this softening is a positive product of organisational evolution in their suggestion:

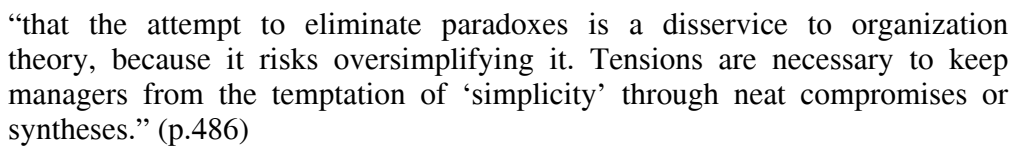

These tensions trigger problem solving and the exploration of new ways of resolving uncertainty within the organisation. This is the essence of improvisation, which was originally thought to comprise a combination of creativity, intuition, and bricolage (Moorman and Miner, 1998a; Moorman and Miner, 1998b). If we concentrate on the components of this early view of improvisation, it is apparent that all three elements are important to the resolution of organisational problems. Employees can apply creative notions in an attempt to find new ways of solving problems and resolving that organisational uncertainty. Applied intuition is required in order that such activity is bounded by judgement of what may be successful in a given situation, based on past experience and a projected vision of the future scenario. Finally, the arresting effects of bricolage come into play, as most activity within organisations is restricted by a limited supply of human, physical, and financial resources. Returning now to our earlier paradoxes, it is apparent that the requirements for control have to be loosened, temporal 
and organisational space for creative activity has to be created, and team-working and collaboration need to be encouraged, and this allows organisational improvisation to flourish.

There are strong parallels with the oxymoronic here, as paradox requires a similar contradictory stance. Grammatically however, the oxymoron is seen as a more compact statement, usually comprising two successive but essentially antithetical words. The significant difference is however that within paradox there is an assumed requirement for legitimacy, in that a seemingly antithetical situation has an element of integrity. It also appears that the concept of improvisation, which is essentially the unrestrained use of creativity and intuition within an environment constrained by limited resources, and the concepts of control inherent within both the organisation and its management, lead us to a paradoxical situation. The notion that both 'improvisation within management' and 'organisational improvisation' lean towards paradox is therefore a reasonable one.

\section{Organisational improvisation as a legitimate way of achieving}

Although it can be argued that organisational improvisation may at times be an oxymoronic label, and has a number of paradoxical characteristics, there is compelling evidence that it is also growing in influence as a way of achieving the objectives of some modern organisations. Much has been said in the last 20 years or so about the changing nature of work, and the growth of flexible working practices. Organisations are now addressing access to and effective use of the tacit knowledge embedded within the workforce, and the development of routines and procedures to codify that knowledge, so that it is retained within the organisation as employees move on. There is greater emphasis than ever on innovation and experimentation, as product and process life cycles shorten, driven by the accelerating pace of change, and proliferating customer demands.

Improvisation has for some years been a part of, or at least recognised in, organisation theory, but was seen as an organisation dysfunction; either as an unintended outcome (March and Simon, 1958), or as an organisation design failure (MacKenzie, 1986). In recent years however, the perception of improvisation has moved from being an outcome of 'getting things wrong', to being seen as a positive skill in making meaningful decisions and achieving within a limited time-scale, without optimum information and resources. The use of improvisational working practices within the management of organisations is therefore now offered by some as an antidote to the problems and tensions of evolution and temporal challenge. Specifically, Moorman and Miner (1998a), in some earlier empirical work, consider that there are three key outcomes associated with improvisation; adaptation, innovation, and learning. Recently, the mastery of these three important organisational elements has been seen as vital to organisational survival.

Mention has already been made of the evolution of the improvisation literature from 'first stage' articles that use jazz performance as a metaphor for organisational improvisation. Barrett (1998) does however identify a significant limitation to the applicability of the jazz metaphor; the notion of competence. Both musical improvisation and organisational improvisation assume a base level of competence. In reality however, all jazz players do not have the levels of competence required, and this is equally true of employees in organisations. This brings us to one of the problems of encouraging improvisational activity in organisations, which is the development of necessary skills. However, Crossan (1998) considers these issues, and indicates that the skills required for 
improvisation can be developed, allowing improvisers to draw on a library of skills, competencies, and frameworks, together with possible scenarios and past offerings, in the way that a stage performer does, or indeed a jazz musician.

Another important consideration is the set of cultural norms and values that needs to permeate any organisation where improvisation is to be encouraged. Managing improvisation is not about managing process. It is much more concerned about managing behaviours, and stimulating the cognitive and creative skills that reside within the workforce. Such skills tend to require a supportive culture that embraces trust, motivation, and the generation and nurturing of a workforce that is happy to release these skills for the good of the organisation. Augier and Vendolø (1999) suggest that informal knowledge networks help to inform improvisers, and Ciborra (1999) highlights a requirement for improvisers to draw on existing repertoires of skills and knowledge to produce solutions to organisational problems. He also proposes that improvisations will benefit from knowledge networks with strong ties. It follows that a supportive culture, where shared learning is supported, and experimentation is encouraged, will assist with successful improvising. Additionally, those organisations that are able to convert the tacit knowledge and successful improvisations held within the organisation's collective memory to codified knowledge that can be accessed for the benefit of all, will benefit most.

It is apparent from the emerging literature and by considering feedback from managers that improvisational working practices are becoming more accepted within organisations. There are some problems, especially in the considerations surrounding limiting the level and scope of improvisational activity, and relaxing that imposed framework as improvisational skills improve. It is however apparent that improvisation is being adopted within progressive, flexible organisations as a legitimate way of achieving. As there are many issues that impinge on this trend, the next section addresses some of the issues that relate to the use and management of improvisational working in the modern organisation.

\section{Improvisation and the modern organisation}

It could be argued that the three key strategic elements to be managed in modern organisations are time, cost, and complexity. The importance of the first two of these three elements is easily explained, although the emphasis may differ according to sector. Notwithstanding Porter's (1985) assertion that there are three principal strategies that an organisation can follow (innovation, quality enhancement, or cost reduction), any organisation operating within the private sector needs to offer a product or service that a customer wants to purchase. Success therefore depends on providing that product or service in a timely manner, and at a cost that the customer is prepared to pay. Public sector organisations are still required to provide a timely service, but costing is focused on optimising budgets to deliver maximum volume of a service, rather than driving down costs to maximise profit.

Traditionally, the management of time, cost, and complexity within organisations revolved around detailed planning, followed by the execution of the outcomes of the planning process with the minimum of variation. It has however become apparent that the environment within which organisations operate is far from stable, and the competitive advantage literature is an important indicator of compacted temporal and budgetary 
pressures that are intensifying competition and focusing the attentions of management on multiple internal and external factors (Thomas et al., 1999). Within the organisation, the management of those three components of time, cost, and complexity are intimately affected by internal factors and resource availability, and the Resource-based View of the organisation is an accepted lens for analysis.

Improvisation may however be able to assist with the modification of mechanisms and routines to facilitate improvements in both time and cost reduction. The reduction of complexity is more problematical. The accepted view of external environmental change is that it has accelerated in tempo and complexity, although this was disputed a decade or so ago (Mintzberg, 1994). Improvisation has however been linked to this perceived acceleration in the pace of change, with Crossan (1997) suggesting that many companies have created an over-reliance on the planning process, which because of its long time horizons, cannot be described as a creative and spontaneous process. She suggests that in the latter part of the 1990s: “...faster, better, smarter" (Crossan, 1997, p.39) business environment there is a requirement for faster cycle times and more innovative solutions, a theme that appears to be holding true in the first few years of the 21 st century.

There is however a view, first mooted by Moorman and Miner (1988b), that improvisation may be: "driven by firm mismanagement, environmental change, or the decision to use improvisation purposefully as part of firm strategy" (p.15). These three perspectives are dramatically different. Research into the use of improvisational work routines within project-managed change in the UK financial services sector (Leybourne, 2002) exposes examples of each of these occurrences. Other commentators on the use of improvisation within organisations have echoed this opinion.

The mismanagement of firms is an area where considerable research activity has been directed. Some of this mismanagement has been attributed to the use of rigid and inflexible strategic planning systems. Cunha et al. (2001, p.67) suggest that: "plans are to organizations what scores are to jazz musicians", inferring that the strategic plan is at best only a 'guide' to the future direction of an organisation. Such a plan is however a route-map that offers shared responsibility based on shared input to its content. It is therefore easier to abdicate responsibility for errors caused by slavish adherence to its content. There is little doubt that improvisation is often used to remedy shortcomings in such plans, and to resolve unforeseen and unexpected issues. Improvisation forces employees to take responsibility for their actions, as there will be no validated or agreed plan to support decisions. Such improvisation is therefore often surreptitious, as such action puts the employee or manager at risk, exposing their actions to unwelcome scrutiny in the event that improvisational actions are less than wholly successful. This perspective of improvisation is however substantially reactive, and does not reflect favourably on organisational improvisation as a new addition to the lexicon of working styles.

Improvisation driven by environmental change is different in both concept and philosophy. Rather than use as a means of remedying shortcomings and repairing potential damage caused by poor planning or execution, improvisation now becomes a legitimate means of reacting to change in the internal and external environments within which the organisation operates. Such action is supported by a wide range of academic literature, from Mintzberg's 'emergent strategy' model, to Ciborra's (1999) comments on the effects of temporal pressure on the organisation, and Crossan's (1997, p.39) previously articulated opinions about modern organisations needing to be: “...faster, better, smarter". Crossan et al. (1996, p.23) suggest that: "significant parts of the 
business environment are largely unpredictable, and... the key task for managers is to explore and innovate in chaotic conditions." They offer improvisational working practices as a way of stimulating flexibility, innovation, and learning, each of which they consider important in coping with an unstable and fast changing business environment. Ciborra (1999) confirms this stance, stating that: "the increasing complexity and rate of change of business circumstances put strain on and limit planning and structure in decision making" (p.91). Chelariu et al. (2002) reinforce this, suggesting that the growing interest in improvisation is:

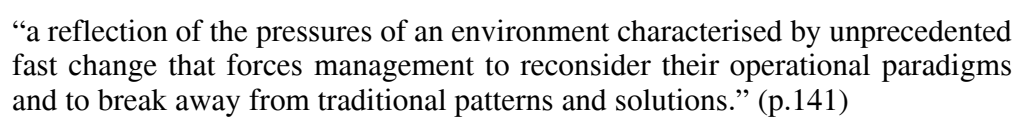

Cunha et al. (2001) take this idea further, proposing that improvisational scenario planning can: "create an action infrastructure for allowing organizations to plan in realtime, as events and action unfold" (p.67). They also urge that: "the ready-aim-fire of planning... [be] replaced by the fire-fire-fire of experimental action" (Cunha et al., 2001, p.68). They further suggest that this mode of organisational thinking is influenced by four principles; the need for more tolerance of uncertainty, a requirement for the abandonment of visible control, the primacy of the informal organisation, and the fact that only employees that are close to the customer have enough clear information to act according to market challenges and opportunities in a timely fashion. These four principles, supported by a view that the future for any given organisation is not an extrapolation from the past, and the fact that the most useful decisions are those that are arrived at quickly, offer a compelling argument for the views of Cunha et al. We can therefore appreciate the benefits of this mode of improvisation as a proactive means of reacting to the changing environment within which organisations operate, and the challenges thrown up by the use of the Resource-based View lens as a means of informing the organisational planning process.

The decision to use improvisational working practices 'purposefully' as an intentional means of managing innovation and change is a wholly proactive stance, and is an extension of the views of Crossan et al. (1996) and Cunha et al. (2001) as they are articulated in the previous paragraphs. There are however many areas of organisational theory and practice to be considered in adopting this stance, including those of trust, motivation, control, and culture. Ciborra (1999) suggests that:

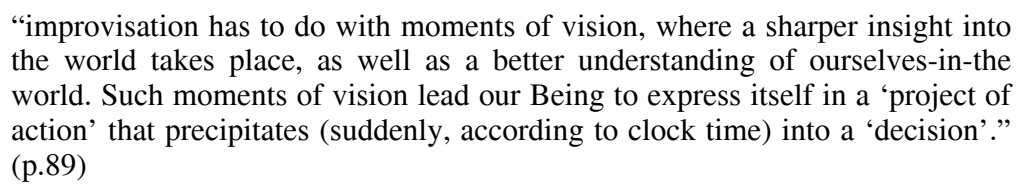

The inference here is that during immersion in a problematical situation that needs resolving immediately, an employee will draw on past experience, intuition, the resources they have to hand, and an element of creativity, and will resolve the problem in the way they feel will be most effective. This is the essence of bricolage, which was identified by Moorman and Miner (1998a; 1998b) as one of the essential constructs of organisational improvisation. It is however important to note that the decision arrived at by applying improvisational practices may not be the 'right' decision, but it is the decision that the improvising employee deemed to be the 'appropriate' decision at the time it was made. 
It is apparent from the extant literature that improvisation is not the panacea to all organisational ills. Indeed, it is difficult to recommend the wholesale dismantling of the traditional models of planning-based management in favour of the potential anarchy of untrammelled and uncontrolled improvisation. Because improvisation disrupts procedures, which are assumed to be the optimal way of carrying out tasks within traditionally managed organisations, some other element of 'implied' control must be present. It is therefore important to provide a 'framework' within which employees can improvise, and to set boundaries that are flexible, and that can be relaxed as trust is built and the culture adapts to embrace effective improvisational working. Brown and Eisenhardt (1997, p.16) call this a 'limiting structure', and suggest that it: "provides the overarching framework without which there are too many degrees of freedom".

\section{Conclusions}

Interestingly, at the start of this section it is appropriate to return to Weick and Wesley (1996). They suggest that:

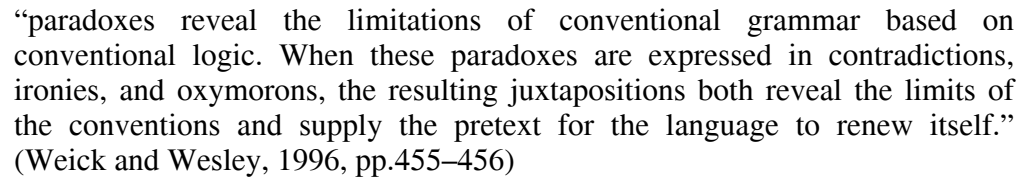

There is an assumption here that Weick and Wesley are talking about the renewal of the language of management, and that this comes about as a result of the renewal of ideas and conventions about how management evolves. Certainly, since the early 1990s there has been a move from improvisation being seen as an organisational 'dysfunction', in that it led away from the traditional incremental route of 'plan, then implement' (Quinn, 1980). This move has seen improvisation embraced as a useful and effective means of both planning and achieving within modern organisations.

If we now return to the original premise of this paper, each of the suggestions in the title requires examination. There is evidence that, when considered traditionally against existing, long established, and well proven management techniques, improvisational working practices appear not only radical, but also somewhat contradictory. Certainly, when reviewed in the light of the historic tendency towards Fayol's (1949) 'plan, organise, command, coordinate, and control' model, the use of improvisation undoubtedly appears to be oxymoronic. The same argument could be used in support of the paradoxical nature of improvisation. There is however a rising volume of empirical research indicating that the effective use of improvisational working practices exists within progressive and forward-thinking organisations, and there may be an valid argument for the acceptance of improvisation as a legitimate way of achieving management objectives. This leads us to examine where this evolving acceptance is taking us as a profession. Whether improvisational working practices could be construed as a new paradigm is questionable. There is little doubt that improvisation has changed the way in which some organisations are managed and operated, but a new paradigm infers more widespread acceptance than we can currently identify. However, if we accept at face value the perceived benefits of improvisational working practices as explored in this paper and the expanding body of other literature, we may be moving in this direction. 


\section{References}

Akgün, A.E. and Lynn, G.S. (2002) 'New product development team improvisation and speed-to-market: an extended model', European Journal of Innovation Management, Vol. 5, No. 3, pp.117-129.

Akgün, A.E., Lynn, G.S. and Byrne, J.C. (2003) 'Organizational learning: a socio-cognitive framework', Human Relations, Vol. 56, No. 7, pp.839-868.

Andriopoulos, C. (2003) 'Six paradoxes in managing creativity: an embracing act', Long Range Planning, Vol. 36, pp.375-388.

Augier, M. and Vendolø, M.T. (1999) 'Networks, cognition and management of tacit knowledge', Journal of Knowledge Management, Vol. 3, No. 4, pp.252-261.

Baker, T., Miner, A.S. and Eesley, D.T. (2003) 'Improvising firms: bricolage, account giving, and improvisational competencies in the founding process', Research Policy, Vol. 32, pp.255-276.

Barrett, F. (1998) 'Creativity and improvisation in jazz and organizations: implications for organizational learning', Organization Science, Vol. 9, No. 5, pp.605-622.

Beer, M. (2001) 'How to develop an organization capable of sustained high performance: embrace the drive for results-capability development paradox', Organizational Dynamics, Vol. 29, No. 4, pp.233-247.

Beltramini, R.F. (2003) 'Advertising ethics: the ultimate oxymoron?', Journal of Business Ethics, Vol. 48, No. 3, pp.215-216.

Bijisma-frankema, K. and Koopman, P. (2004) 'The oxymoron of control in an era of globalisation: vulnerabilities of a mega myth', Journal of Managerial Psychology, Vol. 19, No. 3, pp.204-217.

Brown, S.L. and Eisenhardt, K.M. (1997) 'The art of continuous change: linking complexity theory and time-paced evolution in relentlessly shifting organizations', Administrative Science Quarterly, Vol. 42, No. 1, pp.1-34.

Cameron, K.S. and Quinn, R.E. (1988) 'Organizational paradox and transformation', in R.E. Quinn and K.S. Cameron (Eds.) Paradox and Transformation: Toward a Theory of Change in Organization and Management, Cambridge, MA: Ballinger, pp.1-18.

Chelariu, C., Johnston, W.J. and Young, L. (2002) 'Learning to improvise, improvising to learn: a process of responding to complex environments', Journal of Business Research, Vol. 55, pp.141-147.

Ciborra, C.U. (1999) 'Notes on improvisation and time in organizations', Accounting, Management, \& Information Technology, Vol. 9, pp.77-94.

Clegg, S.R., Cunha, J.V. and Cunha, M.P. (2002) 'Management paradoxes: a relational view', Human Relations, Vol. 55, No. 5, pp.483-503.

Collins, J.W. (1994) 'Is business ethics an oxymoron?', Business Horizons, Vol. 37, No. 5, pp.1-8.

Crossan, M.M. (1997) 'Improvise to innovate', Ivey Business Quarterly, Autumn, pp.36-42.

Crossan, M.M. (1998) 'Improvisation in action', Organization Science, Vol. 9, No. 5, pp.593-599.

Crossan, M.M., Lane, H.W., White, R.E. and Klus, L. (1996) 'The improvising organization: where planning meets opportunity', Organizational Dynamics, Spring, pp.20-35.

Cunha, M.P. and Cunha, J.V. (2001) 'Managing improvisation in cross cultural virtual teams', International Journal of Cross Cultural Management, Vol. 1, No. 2, pp.187-208.

Cunha, M.P. and Cunha, J.V. (2003) 'Organisational improvisation: two syntheses and a filled gap', Journal of Organizational Change Management, Vol. 16, No. 2, pp.169-185.

Cunha, J.V., Cunha, M.P. and Correia, M.F. (2001) 'Scenarios for improvisation: long range planning redeemed', Journal of General Management, Vol. 27, No. 2, pp.67-80.

Cunha, M.P., Cunha, J.V. and Kamoche, K. (1999) 'Organizational improvisation: what, when, how and why', International Journal of Management Reviews, Vol. 1, pp.299-341. 
Davis, A.S., Maranville, S.J. and Obloj, K. (1997) 'The paradoxical process of organizational transformation: propositions and a case study', in W.A. Pasmore and R.W. Woodman (Eds.) Research in Organizational Change and Development, Greenwich, CT: JAI, Vol. 10, pp.275-314.

Dery, D.A. (1998) 'Bank retailing: oxymoron or opportunity?', ABA Banking Journal, Vol. 90, No. 6, pp.83-86.

Duska, R. (2000) 'Business ethics: oxymoron or good business', Business Ethics Quarterly, Vol. 10, No. 1, pp.111-129.

Eisenhardt, K.M. (1997) 'Strategic decisions and all that jazz', Business Strategy Review, Vol. 8, No. 3, pp.1-3.

Eisenhardt, K.M. and Tabrizi, B.N. (1995) 'Accelerating adaptive processes: product innovation in the global computer industry', Administrative Science Quarterly, Vol. 40, pp.84-110.

Fayol, H. (1949) General and Industrial Management, London: Pitman.

Gregory, A. (2003) 'Ethics in communication management: an oxymoron?', Journal of Communication Management, Vol. 8, No. 1, pp.6-8.

Grice, S. and Humphries, M. (1997) 'Critical management studies in postmodernity: oxymorons in outer space?', Journal of Organizational Change Management, Vol. 10, No. 5, pp.412-425.

Hashai, N. and Almor, T. (2004) 'Gradually internationalizing "born global” firms: an oxymoron?', International Business Review, Vol. 13, No. 4, pp.465-483.

Hatch, M.J. (1999) 'Exploring the empty pages of organizing: how improvisational jazz helps redescribe organizational structure', Organization Studies, Vol. 20, No. 1, pp.75-100.

Hatch, M.J. and Ehrlich, S.B. (1993) 'Spontaneous humour as an indicator of paradox and ambiguity in organizations', Organization Studies, Vol. 14, No. 4, pp.505-526.

Hmieleski, K.M. and Corbett, A.C. (2003) 'Improvisation as a framework for investigating entrepreneural action', Unpublished paper presented to the Academy of Management Conference, Seattle, 1-6 August.

Hood, C. (2004) 'The middle aging of new public management: into the age of paradox?', Journal of Public Administration Research and Theory, Vol. 14, No. 3, pp.267-282.

Kahn, W.A. (2002) 'Managing the paradox of self-reliance', Organizational Dynamics, Vol. 30, No. 3, pp.239-256.

Kamoche, K. and Cunha, M.P. (2001) 'Minimal structures: from jazz improvisation to product innovation', Organization Studies, Vol. 22, No. 5, pp.733-764.

Kan, M.M. and Parry, K.W. (2004) 'Identifying paradox: a grounded theory of leadership in overcoming resistance to change', Leadership Quarterly, Vol. 15, No. 4, pp.467-491.

Kanter, R.M. (2002) 'Strategy as improvisational theater', MIT Sloan Management Review, Winter, pp.76-81.

Kilbourne, W.E. (1995) 'Green advertising: salvation or oxymoron?', Journal of Advertising, Vol. 24, No. 2, pp.7-19.

Law, M., Lau, T. and Wong, W.H. (2003) 'From customer relationship management to customer-managed relationship: unravelling the paradox with a co-creative perspective', Marketing Intelligence \& Planning, Vol. 21, No. 1, pp.51-60.

Levy-Strauss, C. (1966) The Savage Mind, Chicago: University of Chicago Press.

Lewis, M.W. and Dehler, G.E. (2000) 'Learning through paradox: a pedagogical strategy for exploring contradictions and complexity', Journal of Management Education, Vol. 24, No. 6, pp.708-725.

Leybourne, S.A. (2002) 'Project management and the implementation of strategic change within the UK financial services sector', Unpublished PhD diss., Cardiff Business School.

Leybourne, S.A. and Sadler-Smith, E. (2004) 'Going-with-your-gut: the role of intuition and improvisation in project management', Unpublished Paper Presented to the Academy of Management Conference, New Orleans, 6-13 August. 
Littler, C.R. and Innes, P. (2004) 'The paradox of managerial downsizing', Organization Studies, Vol. 25, No. 7, pp.1159-1184.

Ma, H., Karri, R. and Chittipeddi, K. (2004) 'The paradox of managerial tyranny', Business Horizons, Vol. 47, No. 4, pp.33-40.

MacKenzie, K.D. (1986) 'Virtual positions and power', Management Science, Vol. 32, pp.622-642.

Macredie, R.D. and Sandom, C. (1999) 'IT-enabled change: evaluating an improvisational perspective', European Journal of Information Systems, Vol. 8, pp.247-259.

March, J.G. and Simon, H.A. (1958) Organizations, New York: Wiley.

McGinn, K.L. and Keros, A.T. (2002) 'Improvisation and the logic of exchange in socially embedded transactions', Administrative Science Quarterly, Vol. 47, pp.442-473.

Meirowitz, R. (2004) 'Resolving the innovation paradox: enhancing growth in technology companies', Research Technology Management, Vol. 47, No. 5, p.63.

Miner, A.S., Bassoff, P. and Moorman, C. (2001) 'Organizational improvisation and learning: a field study', Administrative Science Quarterly, Vol. 46, pp.304-337.

Mintzberg, H. (1994) The Rise and Fall of Strategic Planning, London: Prentice Hall.

Mohr, J.J. and Sengupta, S. (2002) 'Managing the paradox of inter-firm learning: the role of governance mechanisms', Journal of Business and Industrial Marketing, Vol. 17, No. 4, pp.282-301.

Montuori, A. (2003) 'The complexity of improvisation and the improvisation of complexity: social science, art, and creativity', Human Relations, Vol. 56, No. 2, pp.237-255.

Moorman, C. and Miner, A.S. (1998a) 'Organizational improvisation and organizational memory', Academy of Management Review, Vol. 23, pp.698-723.

Moorman, C. and Miner, A.S. (1998b) 'The convergence of planning and execution: improvisation in new product development', Journal of Marketing, Vol. 62, pp.1-20.

O'Connor, E.S. (1995) 'Paradoxes of participation: textual analysis and organizational change', Organization Studies, Vol. 16, No. 5, pp.769-803.

Orlikowski, W.J. (1996) 'Improvising organizational transformation over time: a situated change perspective', Information Systems Research, Vol. 7, No. 1, pp.63-92.

Orlokowski, W.J. and Hoffman, J.D. (1997) 'An improvisational model for change management: the case of groupware technologies', Sloan Management Review, Winter, pp.11-21.

Orr, K. (2004) 'Agile requirements: opportunity or oxymoron?', IEEE Software, Vol. 21, No. 3, pp.71-73.

Ozley, L.M. (2000) “"Ethical consulting” does not have to be an oxymoron', Organizational Dynamics, Vol. 28, No. 4, pp.38-51.

Pavlovich, K. (2003) 'All that jazz', Long Range Planning, Vol. 36, pp.441-458.

Pearlson, K.E. and Saunders, C.S. (2001) 'There's no place like home: managing telecommuting paradoxes', Academy of Management Executive, Vol. 15, No. 2, pp.117-128.

Poole, M.S. and Van de Ven, A.H. (1989) 'Using paradox to build management and organization theories', Academy of Management Review, Vol. 14, No. 4, pp.562-578.

Porter, M.E. (1985) Competitive Advantage, New York: Free Press.

Quinn, J.B. (1980) Strategies for Change: Logical Incrementalism, Homewood, IL: Richard D. Irwin.

Roberts, N.C. (2002) 'Keeping public officials accountable through dialogue: resolving the accountability paradox', Public Administration Review, Vol. 62, No. 6, pp.658-669.

Russ-Eft, D. (2004) 'Ethics in a global world: an oxymoron?', Evaluation \& Program Planning, Vol. 27, No. 3, pp.349-356.

Ryle, G. (1979) On Thinking, Oxford: Basil Blackwell. 
Starrat, R.J. (2001) 'Democratic leadership theory in late modernity: an oxymoron or ironic possibility?', International Journal of Leadership in Education, Vol. 4, No. 4, pp.333-352.

Selladurai, R.S. (2004) 'Mass customization in operations management: oxymoron or reality?', OMEGA - International Journal of Management Science, Vol. 32, No. 4, pp.295-300.

Snowden, D. (2002) 'Complex acts of knowing: paradox and descriptive self-awareness', Journal of Knowledge Management, Vol. 6, No. 2, pp.100-111.

Sundaramurthy, C. and Lewis, M. (2003) 'Control and collaboration: paradoxes of governance', Academy of Management Review, Vol. 28, No. 3, pp.397-415.

Thomas, H., Pollock, T. and Gorman, P. (1999) 'Global strategic analysis: frameworks and approaches', Academy of Management Executive, Vol. 13, No. 1, pp.70-82.

Thornberry, N. (2001) 'Corporate entrepreneurship: antidote or oxymoron?', European Management Journal, Vol. 19, No. 5, pp.526-533.

Van de Ven, A.H. and Poole, M.S. (1995) 'Explaining development and change in organizations', Academy of Management Review, Vol. 20, No. 3, pp.510-540.

Van den Broek, D., Callaghan, G. and Thompson, P. (2004) 'Teams without team-working?: Explaining the call centre paradox', Economic and Industrial Democracy, Vol. 25, No. 2, pp.197-218.

van Thiel, S. and Leeuw, F.L. (2002) 'The performance paradox in the public sector', Public Performance \& Management Review, Vol. 25, No. 3, pp.267-281.

Vega, G. (1998) 'Ethical telemarketing: oxymoron contested', Review of Business, Vol. 20, No. 1, pp.17-21.

Vera, D. and Crossan, M. (2004) 'Theatrical improvisation: lessons for organizations', Organization Studies, Vol. 25, No. 5, pp.727-749.

Weick, K.E. (1979) The Social Psychology of Organizing, 2nd ed., Reading, MA: Addison-Wesley Publishing Company.

Weick, K.E. (1998) 'Improvisation as a mindset for organizational analysis', Organization Science, Vol. 9, No. 5, pp.543-555.

Weick, K.E. and Wesley, F. (1996) 'Organizational learning: affirming an oxymoron', in S.R. Clegg, C. Hardy and W.R. Nord (Eds.) Handbook of Organizational Studies, London: Sage Publications.

Yates-Mercer, P. and Bawden, D. (2002) 'Managing the paradox: the valuation of knowledge and knowledge management', Journal of Information Science, Vol. 28, No. 1, pp.19-29.

Yu, L. (2002) 'Is global software an oxymoron?', MIT Sloan Management Review, Vol. 43, No. 3, pp.9-11.

Zigurs, I. (2003) 'Leadership in virtual teams: oxymoron or opportunity?', Organizational Dynamics, Vol. 31, No. 4, pp.339-351. 